\title{
The Journal of African History
}

http://journals.cambridge.org/AFH

Additional services for The Journal of African History:

Email alerts: Click here

Subscriptions: Click here

Commercial reprints: Click here

Terms of use : Click here

\section{THE HISTORIOGRAPHY OF ISLAM IN WEST AFRICA: AN ANTHROPOLOGIST'S VIEW}

\section{Benjamin Soares}

The Journal of African History / Volume 55 / Issue 01 / March 2014, pp 27 - 36

DOI: 10.1017/S0021853713000819, Published online: 01 April 2014

Link to this article: http://journals.cambridge.org/abstract_S0021853713000819

How to cite this article:

Benjamin Soares (2014). THE HISTORIOGRAPHY OF ISLAM IN WEST AFRICA: AN ANTHROPOLOGIST'S VIEW . The Journal of African History, 55, pp 27-36 doi:10.1017/ S0021853713000819

Request Permissions : $\underline{\text { Click here }}$ 


\title{
JAH Forum
}

\section{THE HISTORIOGRAPHY OF ISLAM IN WEST AFRICA: AN ANTHROPOLOGIST'S VIEW *}

\author{
Benjamin Soares \\ Afrika-Studiecentrum, Leiden
}

\begin{abstract}
In this article, I focus on the historiography of Islam in West Africa while also reflecting upon and assessing existing scholarship in the broader field of the study of Islam in Africa. My position as an anthropologist who conducts historical research informs my perspective in evaluating the current state of the field and my suggestions for directions in which I think future research might move in order to advance our understanding of Islam and Muslim societies and the history of religious life in Africa more generally.
\end{abstract}

\section{Key Words}

Islam, religion, historiography, anthropology, Western Africa.

Before considering how the history of Islam has been studied in West Africa, it is important to remember how marginal sub-Saharan Africa in general has been to academic discussions of Islam in the world and the understanding of Islamic history. ${ }^{\mathrm{I}}$ Moreover, in the study of religion in Africa, Islam has also been relatively marginalized, and not just by historians. I want to begin with anthropology, my own academic discipline. It is striking how until quite recently anthropologists have generally avoided the study of Islam in sub-Saharan Africa. $^{2}$ Most anthropologists who have worked in sub-Saharan Africa and had an interest in 'religion' have devoted much of their attention to what was called not so long ago 'primitive', 'tribal' religions, and more recently 'traditional' religion or so-called African traditional religion (ATR). When they have studied 'religion' among Muslims in Africa they have often studied such purportedly African religion in such guises as spirit possession or trance. In fact, spirit possession-an over-studied topic if there ever was one in African studies and Africanist anthropology more specifically - has been a major focus of attention. Some of this research has focused on issues of gender and sought to

* I am grateful to John O. Hunwick for the many stimulating exchanges that have informed this essay and to Robert Launay, Rüdiger Seesemann, and four anonymous reviewers for their critical readings of earlier drafts. Author's email: bsoares@ascleiden.nl

I The already existing essentialist thinking about Islam and Muslims both within and outside the academy that has proliferated even further in the post-September I I, 200 I era has had implications for the study of Africa that are beyond the scope of this essay. See B. F. Soares and R. Otayek (eds.), Islam and Muslim Politics in Africa (New York, 2007).

2 R. Launay, 'An invisible religion?: anthropology's avoidance of Islam in Africa', in M. Ntarangwi, D. Mills, and M. Babiker (eds.), African Anthropologies: History, Critique and Practice (Dakar, 2006), I88-203; and M. Saul, 'Islam and West African anthropology', Africa Today, 53:I (2006), 3-33. 
study women's religious practice particularly through the lens of spirit possession. Be that as it may, the longstanding anthropological preoccupation with spirit possession and trance in Africa is perhaps because such phenomena are assumed to be instances of the 'traditional', the exotic, or the 'ecstatic', and, therefore, presumably characteristically 'African'. Although I have I. M. Lewis's work on spirit possession specifically in mind here, such a focus is apparent in recent studies of postcolonial Muslim Africa, particularly some of the most widely discussed and debated. ${ }^{3}$ In short, anthropologists long tended to write about those kinds of religion they were expected to look for and study during fieldwork in small communities of one sort or another in Africa, in other words, not a religion assumed to have been imported into sub-Saharan Africa. Islam-practiced in sub-Saharan Africa and West Africa in particular for more than a millennium-was generally not deemed a proper topic for research for most anthropologists.

The neglect of Islam and Muslim societies in Africa by anthropologists is even more astonishing when one considers that anthropologists (not to mention sociologists, historians, and religious studies scholars) have long taken an interest in Christianity in Africa. There are many noteworthy studies of the history of Christian missionary activities in Africa, 'conversion' to Christianity, African independent churches, and resistance to Western hegemony by African Christians. Some of the most influential by anthropologists include monographs by J. D. Y. Peel, Johannes Fabian, T. O. Beidelman, and Jean and John Comaroff. ${ }^{4}$ It is remarkable that there is no comparable anthropological research about the history of Islam in Africa, African Muslims, or Islamization. ${ }^{5}$ The more recent scholarly preoccupation with Pentecostalism in Africa especially by anthropologists indexes, if anything, the continuing exoticizing gaze of Western academics, who seem to prefer to focus on forms of religion that exhibit features - speaking in tongues and the gospel of prosperity in particular - that are seemingly alien to Western sensibilities rather than, say, middle-class mainline Protestants or Roman Catholics in contemporary Africa. Moreover, it illustrates the widespread assumption that somehow the mainline Protestant churches and the Roman Catholic Church are less dynamic than Pentecostalism in Africa and therefore presumably less important to study.

Before turning to some recent research about West Africa, I would like to review some of the major trends in the historiography of Islam in West Africa that I am only able to discuss in abbreviated fashion. ${ }^{6}$ As noted above, anthropologists long seemed to have cornered

3 See, for example, I. M. Lewis, Ecstatic Religion: An Anthropological Study of Spirit Possession and Shamanism (London, I97I). For West Africa, see P. Stoller, Embodying Colonial Memories: Spirit Possession, Power, and the Hauka in West Africa (New York, I995); and A. M. Masquelier, Prayer has Spoiled Everything: Possession, Power, and Identity in an Islamic Town of Niger (Durham, NC, 200I).

4 J.D. Y. Peel, Aladura: A Religious Movement among the Yoruba (Oxford, I968); J. Fabian, Jamaa: A Charismatic Movement in Katanga (Evanston, IL, I97I); T. O. Beidelman, Colonial Evangelism: A Socio-Historical Study of an East African Mission at the Grassroots (Bloomington, IN, I982); J. Comaroff and J. L. Comaroff, Of Revelation and Revolution, Volume I: Christianity, Colonialism, and Consciousness in South Africa (Chicago, I99I).

5 In contrast, see the work in religious studies by Patrick J. Ryan on Yoruba Muslims, P. J. Ryan, Imale: Yoruba Participation in the Muslim Tradition: A Study of Clerical Piety (Missoula, MT, I977).

6 See Robert Launay's overview of the study of Islam in Africa, which has informed my own thinking about this topic, in R. Launay, Beyond the Stream: Islam and Society in a West African Town (Berkeley, CA, I992), esp. I4-22. 
the market in the study of religions other than Islam (and to a lesser extent Christianity) in sub-Saharan Africa. In large part, British and American anthropologists left the study of Islam and Muslim societies in Africa to scholars trained as Orientalists and then later as professional historians of Africa. Thus, from the I960s to the I980s various scholars-British, American, French, and then later Africans - studied the medieval West African ('Sudanese') states or empires, such as Ghana or Wagadu (the eighth to the thirteenth centuries), Mali (fourteenth to the sixteenth centuries), and Songhay (which reached its apogee in the sixteenth century). Muslims lived in and sometimes ruled in these polities. Some of these studies of the medieval states relied heavily upon texts written in classical Arabic for their research. For many of the scholars writing about Wagadu, Mali, and Songhay, such empires seemed to represent a classical civilization, analogous to a 'golden age' in Islam. It almost seemed to follow that they discussed these empires in good Orientalist fashion-in terms of stagnation and decline, followed by later, eighteenth- and nineteenth-century revival, reform, and jihad. ${ }^{7}$ These are also familiar themes in the Orientalist vision of Islam. In this way of thinking, Muslims almost seemed predestined to engage in reform, which, in its ultimate expression, seems to come in the form of jihad. This is not to deny the longstanding 'tradition' of reform in Islam instantiated in various kinds of Islamic reform and revival in many Muslim societies over time and space, including in Africa. ${ }^{8}$

It is interesting to note that beginning in the colonial period jihad became a major focus in the study of Islam in West Africa, especially in work on the period of history from the late eighteenth century through the nineteenth century. There was a succession of armed struggles involving Muslim religious leaders immediately before and during the period of expansion and consolidation of European colonial rule in the mid- to late nineteenth century in West Africa. Such jihads were for obvious reasons a concern and preoccupation of colonial powers that sought to thwart any threats to their rule. Perhaps for the very same reasons these armed struggles were important to some of the nationalist historiography produced after independence from European colonial rule. ${ }^{9}$

Scholars interested in the transition to colonial rule also took up the theme of jihad in the early years of the development of African history as a subdiscipline. Beginning with Murray Last's PhD thesis published as The Sokoto Caliphate in 1967 and Mervyn Hiskett's Sword of Truth, scholars described Usman dan Fodio's (d.I8I7) hijra (Arabic, retreat), subsequent jihad against 'pagans' (and the Muslims he accused of not being proper Muslims), and the founding of the Sokoto caliphate in the early

7 See, for example, J. Cuoq, Histoire de l'islamisation de l'Afrique de l'Ouest: des origines à la fin du XVIe siècle (Paris, I984); J.-C. Froelich, 'Essai sur l'islamisation de l'Afrique noire', Le Monde Religieux, n.s. 29 (I966), 28I-93; and J. S. Trimingham, A History of Islam in West Africa (London, I962).

8 On traditions of Islamic reform in Africa, see R. Loimeier, 'Patterns and peculiarities of Islamic reform in Africa', Journal of Religion in Africa, 33:3 (2003), 237-62; and R. Loimeier, 'Traditions of reform, reformers of tradition: case studies from Senegal and Zanzibar/Tanzania', in Z. A. Hirji (ed.), Diversity and Pluralism in Islam: Historical and Contemporary Discourses Amongst Muslims (London, 2010), I35-62.

9 J. Hargreaves, 'The Tokolor empire of Ségou and its relations with the French', in J. Butler (ed.), Boston University Papers on Africa, Volume II: African History (Boston, I966), I25-45; also see D. Robinson, The Holy War of Umar Tal: The Western Sudan in the Mid-Nineteenth Century (Oxford, I985). 
nineteenth century. ${ }^{\text {Io }}$ There have also been several major studies of the large-scale jihads of the mid- to late nineteenth century involving al-Hajj Umar Tall and his successors and the later wars of Samori Touré (d. I900). ${ }^{\text {I }}$ The focus on jihad and the polities or states that came in the wake of such armed conflict in West Africa reflected prevailing broader trends in African historiography that were state-centric. The perspectives offered also seem to relate to the availability of sources from and by the 'victors'. Historians have variously described such jihads and conflicts in West Africa as 'revolutions,' forms of anti-colonial resistance, proto-nationalism, empire- and state-building projects, social movements, and instances of the progressive Islamization of Muslims and non-Muslims. These differing interpretations aside, I would like to emphasize that by focusing on jihad and relying upon rather mechanical models of reform the historiography has tended to create the illusion of a teleology. In other words, Muslims somehow seem programmed to fight jihad as they put Islamic doctrine-apparently assumed to be relatively timeless and unchanging - into practice.

In the period of ascendancy of Marxian analysis, some historians of West Africa have advanced largely materialist analyses that arguably did not take Islam as a religion seriously into consideration. Indeed, such analyses tended to treat Islam and Islamic religious culture as epiphenomenal. ${ }^{\mathrm{I2}}$ In contrast to the considerable research on jihad, there was a much smaller body of historical work about Muslims in West Africa who have been resolutely against jihad. Notably, there was Ivor Wilks's brief but influential work on al-Hajj Salim Suware from Dia in Macina (early sixteenth century), the scholar who many in the broader region have claimed as a model for rejecting ih ad. $^{\mathrm{I} 3}$ Lamin Sanneh's PhD thesis about a group of 'quiescent' Muslim clerics in the Senegambia published as The Jakhanke was a rare study that stood out for not focusing on jihad but rather on the long tradition of peaceful interactions between Muslims and non-Muslims. ${ }^{\mathrm{I}}$

Another major trend in the historiography of Islam in West Africa, particularly strong in France, focused upon the history of the region's different Sufi orders, that is, the mystical traditions in Islam, particularly the Qadiriyya and the Tijaniyya. Arguably, some of this attention came because key actors in the nineteenth-century jihads were associated with one or another Sufi order-hence the colonial preoccupation and obsession with Sufi orders and their leaders. ${ }^{\mathrm{I}}{ }^{2}$ In fact, al-Hajj Umar Tall has been widely credited with having introduced the Tijaniyya into large parts of West Africa, and some of his Muslim

Io M. Last, The Sokoto Caliphate (London, 1967); M. Hiskett, The Sword of Truth: The Life and Times of the Shehu Usuman dan Fodio (New York, 1973).

I I On Umar Tall, see Robinson, Holy War; and M. Ly-Tall, Un Islam militant en Afrique de l'Ouest au XIXe siècle: la Tijaniyya de Sä̈ku Umar Futiyu contre les pouvoirs traditionnels et la puissance coloniale (Paris, I99I). On Samori, see Y. Person, Samori: une révolution dyula, 3 vols. (Dakar, I968-75).

I2 See Lamin Sanneh's critique of such studies in L. Sanneh, 'Review of D. Robinson, The Holy War of Umar Tall: The Western Sudan in the Mid-Nineteenth Century', Journal of Religion in Africa, 18:3 (1988), 286-90.

I3 I. Wilks, 'The transmission of Islamic learning in the Western Sudan', in J. Goody (ed.), Literacy in Traditional Societies (Cambridge, 1968), I62-97.

I4 L. Sanneh, The Jakhanke: The History of an Islamic Clerical People of the Senegambia (London, I979).

I 5 J.-L. Triaud, 'Le thème confrérique en Afrique de l'ouest', in A. Popovic and G. Veinstein (eds.), Les ordres mystiques dans l'Islam: cheminements et situation actuelle (Paris, I986), 27I-82; B. F. Soares, 'Rethinking Islam and Muslim societies in Africa', African Affairs, 106:423 (2007), 319-26. 
adversaries were members of the Qadiriyya. The attention to Sufi orders has been carried over into the postcolonial period, not least given the prevailing view that such Sufi orders might be relevant to political mobilization. There have been a number of important studies of these Sufi orders, various Sufi leaders, the organizational forms of the different Sufi orders, and the relationship between Sufi orders, politics, and economics. There have also been several notable studies of the Mourides, the Sufi order founded by Amadou Bamba (d.r927) in Senegal, though most of that scholarship has been by social scientists and rightly called into question by Jean-Louis Triaud for its tendency toward Mouridocentrism and Senegalocentrism. ${ }^{\text {I6 }}$

More recently, scholars have carried this tradition forward by writing about various branches of the Qadiriyya and the Tijaniyya in West Africa during the colonial era and after. ${ }^{17}$ The different Sufi orders in West Africa have also been variously analyzed as forms of nascent nationalism, proto-political projects, social movements, and instances of progressive Islamization. In some countries, various Muslim religious leaders associated with Sufi orders have been elevated to the status of anti-colonial resistance figures, most notably, Amadou Bamba and al-Hajj Umar Tall in Senegal. However, it is instructive to note how interpretations of the jihad of al-Hajj Umar have differed quite markedly. If many see him as a unifying proto-nationalist figure in Senegal, he is a much more controversial and divisive figure in Mali given the internecine battles between various Muslim groups that marked his passage in the region. ${ }^{\mathrm{I} 8}$

Given that Sufism is commonly characterized as the mystical tradition in Islam, it is surprising that until quite recently most scholars avoided studying the 'spiritual' aspects of the Sufi orders in West Africa. ${ }^{\text {I9 }}$ The same could also be said of the rich intellectual history of African Muslims for that matter. ${ }^{20}$ Cheikh Babou takes up both the mystical and the intellectual traditions in his book about the Mouride Sufi order, Fighting the Greater Jihad. ${ }^{2 \text { I }}$ According to a hadith, a reported saying of the Prophet Muhammad, the greater jihad, as opposed to the lesser jihad of armed struggle, is the disciplining of the soul. Drawing from a rich base of sources, particularly oral, from within the Mouride tradition, Babou has

I6 Triaud, 'Le thème confrérique', 277.

I7 On the Tijaniyya, see J.-L. Triaud and D. Robinson (eds.), La Tijâniyya: une confrérie musulmane à la conquete de l'Afrique (Paris, 2000) and the detailed studies of some of its important branches by S. Hanretta, Islam and Social Change in French West Africa: History of an Emancipatory Community (Cambridge, 2009); R. Seesemann, The Divine Flood: Ibrahim Niasse and the Roots of a Twentieth-Century Sufi Revival (New York, 20II); B. F. Soares, Islam and the Prayer Economy: History and Authority in a Malian Town (Ann Arbor, MI, 2005); and R. Seesemann and B. F. Soares, "Being as good Muslims as Frenchmen": on Islam and colonial modernity in West Africa', Journal of Religion in Africa 39: I (2009), 9I-I20.

I8 Hargreaves, 'Tokolor empire'.

I9 One important exception is L. Brenner, West African Suf: The Religious Heritage and Spiritual Search of Cerno Bokar Saalif Taal (Berkeley, CA, I984), which drew upon Amadou Hampâté Bâ's earlier and more hagiographic study of the same figure. See A. H. Bâ, Vie et enseignement de Tierno Bokar: le sage de Bandiagara (Paris, I980). A more recent, deeply compelling study that takes religious discourse in the study of Sufism seriously is Seesemann, Divine Flood.

20 Two recent notable exceptions are M.S. Umar, Islam and Colonialism: Intellectual Responses of Muslims of Northern Nigeria to British Colonial Rule (Leiden, 2006); and Seesemann, Divine Flood.

2 I C. A. M. Babou, Fighting the Greater Jihad: Amadu Bamba and the Founding of the Muridiyya of Senegal, I853-I9I3 (Athens, OH, 2007). 
written his book against a dominant tradition that has largely focused on violent jihad without taking religious and intellectual content into serious consideration.

Another significant and longstanding trend in the historiography of Islam in West Africa has been the study of anti-Sufi reformists. It too can be traced to the late colonial preoccupation with modernist and reformist Muslims, who sometimes called colonial authority into question and often challenged the authority of those Muslim religious leadersoften members of Sufi orders - who had established working relationships with colonial authorities. Lansiné Kaba's PhD published in 1974 as The Wabhabiyya: Islamic Reform and Politics in French West Africa was one of the first of such studies of Muslim reformists who opposed Sufi orders, Sufi religious leaders, and their practices. ${ }^{22}$

If studies of jihad, Sufi orders, and reform have implicitly and often inadvertently generated a teleological view of Islam in Africa over time, this is not to deny the importance of these themes in Islamic and African history. But it does show limits to their value in helping us to understand the complexity of Islamic history in Africa. Studies about how Islam arrived in West Africa - via traders, scholars, Sufis - and about how Islam developed in situ often have quite similar limitations. The two most frequently invoked models of the spread of Islam in sub-Saharan Africa are J. Spencer Trimingham's minority, court, and majority model and Humphrey Fisher's model of quarantine, mixture, and reform. ${ }^{23}$ Both models are teleological in that Islam is posited as always and necessarily disposed toward reform and greater purity. More recent histories of Muslim reformists, which seem to have drawn from such models, have tended to suggest that such reform with its rejection of Sufism and its modernizing affinities constitutes an ineluctable process. For example, in her study of reformists in Côte d'Ivoire, Marie Miran even seems to equate Ivoirian Muslim reformists with modernity and suggests that the movement toward Islamic reform is almost inevitable. However, such a teleological view neglects other possible ways of being Muslim and modern. ${ }^{24}$

In spite of his sophisticated and pioneering studies of various aspects of Islam in West Africa, Louis Brenner's influential book, Controlling Knowledge, on the history of Islamic education in Mali is driven by a quite similar teleological argument. ${ }^{25} \mathrm{He}$ claims there is a great-presumably irreversible-shift from an esoteric episteme in 'traditional' Islamic schooling associated with hierarchy, secrecy, and chains of initiation to a rationalist episteme in 'modern' education that is egalitarian and open to all who enter. There are a number of problems with such recurring models of Islamization and change over time that are not limited to Brenner's study. First, African Muslims seem to be measured against standards set elsewhere, usually in North Africa or the Arab Middle East, that is, in the presumed heartlands of Islam. Second, movement toward 'purer' forms of Islam - in earlier

22 L. Kaba, The Wahhabiyya: Islamic Reform and Politics in French West Africa (Evanston, IL, I974); R. Loimeier, Säkularer Staat und islamische Gesellschaft: die Beziehungen zwischen Staat, Sufi-Bruderschaften und islamischer Reformbewegung in Senegal im 20. Jahrhundert (Hamburg, 200I).

23 Trimingham, History of Islam; H. J. Fisher, 'The juggernaut's apologia: conversion to Islam in black Africa', Africa, 55:2 (I985), I 53-73.

24 M. Miran, Islam, histoire et modernité en Côte d'Ivoire (Paris, 2006).

25 L. Brenner, Controlling Knowledge: Religion, Power and Schooling in a West African Muslim Society (Bloomington, IN, 200I). 
scholarship via jihad or reform and now in Brenner's terms more 'rational' ways of being in the world - are made to appear almost inevitable.

Over the past two decades, the study of the history of Islam in Africa has developed into a veritable subfield within African history, and many of the studies I have mentioned have been foundational for this subfield. In the past decade or so, there has been a series of books and monographs published on the history of Islam and various Muslim societies in Africa and an expanding group of scholars who are working on Islam in Africa. In recent years, historians of West Africa, especially those in the younger generation, have focused considerable attention upon the late colonial period and the first decades after independence. Few of these historians have had much to say, if anything, about precolonial West Africa and Islam in particular (see below). There is now a journal Islamic Africa that is associated with Northwestern University's Institute for the Study of Islamic Thought in Africa (ISITA) that John Hunwick founded in 2000; the Brill book series, 'Islam in Africa', which John Hunwick also founded; a broadening of historical topics, some of which have been featured in a West African regional focus recently published by Oxford Islamic Studies Online; and considerable work by social scientists, mostly anthropologists, about contemporary Muslim societies and Islam in West Africa.

To summarize from this brief overview of the historiography of Islam in West Africa, I would like to emphasize that there has been too much attention to Sufi orders or their presumed opposites, Muslim reformists. In addition, there is a marked tendency to assume that Muslims act according to something inherent in Islam - such as reform and jihad. Sufi orders, jihad, and reform (not to mention spirit possession and Pentecostalism) are of course all legitimate topics of research. But when taken together the collective emphasis is implicitly, if not explicitly, teleological and, therefore, rather limiting. Whatever the merits of these earlier studies might be, it is important to go beyond the histories of Muslim scholars, leaders, rulers, and reformists that have been documented in some of those studies to understand the experience of ordinary African Muslims in West Africa. This is an important history that a new generation of scholars has effectively been writing.

If, as noted above, most of those writing West African history today usually do not consider precolonial history, a few recent works do stand out for the light they shed on Islam and Muslim societies in the precolonial period. In his study of the history of 'race' in the areas around the Timbuktu region of present-day Mali, Bruce Hall shows how ideas about differences between groups of people and Muslims in particular predated the colonial period and how such ideas were transformed with the arrival of colonial racialist thinking and notions of hierarchy. ${ }^{26}$ In The Walking Qur'an Rudolph Ware employs Islamic schooling in the longue durée as a lens to explore the West African past and the practice of Islam. ${ }^{27}$ Taking a rather expansive view of history over the last millennium, he presents a global view of the Senegambia and its polities and explores the importance of Islamic education, Islamic culture, centers of learning, and their transformations over time. His approach to knowledge as embodied knowledge and his exploration of bodies of knowledge are rather

26 B. S. Hall, A History of Race in Muslim West Africa, I600-I960 (Cambridge, $201 \mathrm{I}$ ).

27 R. T. Ware III, The Walking Qur'an: Islamic Education, Embodied Knowledge, and History in West Africa (Chapel Hill, NC, 20I4). 
original in the study of Islamic schooling and illustrate how Islam has been interpreted and lived-and embodied - by ordinary Muslims in West Africa over such a long period of time. It is also noteworthy how both of these works challenge scholars of Islam and Muslim societies working on other geographic areas to engage more fully with scholarship on Islam and Muslim societies in Africa.

Among those studies focusing on more recent periods some promising trends that challenge taken-for-granted teleologies include Brian Peterson's study of the long history of the Islamization of rural peoples over multiple generations in southern Mali during the colonial period and Susan O'Brien's gendered reading of northern Nigerian history where she rethinks practices of spirit possession and their importance to ways of being Muslim. ${ }^{28}$ Unlike some earlier studies of reform, three recent books show the complexity of traditions of reform among Muslims in West Africa, including some of those involved in Sufi orders: Ousman Kobo's careful research about Muslim reformists from the late I950s in both Ghana and Burkina Faso and the local roots of such reform; Sean Hanretta's detailed study of the branch of the Tijaniyya associated with Yacouba Sylla, which, he argues, was a movement of reform and an 'emancipatory community' for socially marginal people, as well as for many women; and Rüdiger Seesemann's remarkably close reading of the inner workings of the nascent community that developed around Ibrahim Niasse, perhaps the most important Sufi leader of twentieth-century sub-Saharan Africa, who sought to revive and revitalize the Tijaniyya. ${ }^{29}$

Another particularly promising trend in recent scholarship has been the effort to study Muslims in Africa within broader historical and social contexts and analytical frames. The recent histories and ethnographies of religious encounters in which Muslims and non-Muslims and Islam and other religious traditions have been studied within the same analytical frame have been especially useful for the study of ordinary Africans, their religious practices, and worlds. In his original and innovative work on the history of 'religious encounter', Peel has studied the complex interactions between Christianity, Islam, and practitioners of what has come to be called Yoruba 'religion' in southwestern Nigeria. ${ }^{3 \circ}$ In a meticulous study of one Nigerien Muslim man's conversion narrative in colonial Nigeria, Shobana Shankar has compared how the narrative in his private diary, which shows his life between Islam and Christianity, is markedly different from his life story as a confirmed Christian convert available in more official missionary sources. ${ }^{3 \mathrm{I}}$ Shankar shows that the boundaries between Islam, Christianity, Muslim, Christian, colonizer, and colonized were ambiguous and shifted over time. Both of these studies point to

28 B. J. Peterson, Islamization from Below: The Making of Muslim Communities in Rural French Sudan, I880-I960 (New Haven, CT, 20II); S. M. O'Brien, 'Spirit discipline: gender, Islam, and hierarchies of treatment in postcolonial northern Nigeria', in S. Pierce and A. Rao (eds.), Discipline and the Other Body: Correction, Corporeality, Colonialism (Durham, NC, 2006), 273-302.

29 O. Kobo, Unveiling Modernity in Twentieth-Century West African Islamic Reforms (Leiden, 20I 2); Hanretta, Islam and Social Change; Seesemann, Divine Flood.

30 J. D. Y. Peel, Religious Encounter and the Making of the Yoruba (Bloomington, IN, 2000).

3 I S. Shankar, 'A fifty-year Muslim conversion to Christianity: religious ambiguities and colonial boundaries in northern Nigeria, c. I906-I963', in B. F. Soares (ed.), Muslim-Christian Encounters in Africa (Leiden, 2006), 89-II4. See also Barbara Cooper's important study of converts to Christianity in Niger in B. M. Cooper, Evangelical Christians in the Muslim Sahel (Bloomington, IN, 2006). 
the considerable ambiguities and fraught history of religious encounters with complex patterns of borrowing and appropriation, as well as boundary making, crossing, and dissolution.

Some of my own recent research moves in similar directions. Attempting to go beyond the frame of Islam in Africa and its limitations, I am trying to write the history of changing religious expression in twentieth-century Mali. ${ }^{32}$ This is a world that was characterized by considerably greater mobility; marked increases in urban economic activities and formal education; new forms of 'modern' knowledge and governmentality; and greater global interconnections. In this research, I begin with the spread of Islam among non-Muslims in colonial Mali, particularly the Dogon - the group immortalized in French anthropology as quintessential 'traditional' Africans, who have resisted Islamization. Under French rule, many colonial subjects, including countless Dogon and most of their non-Muslim neighbors, including many slaves, converted to Islam, and, today, the overwhelming majority of Malians and most Dogon identify themselves as Muslims. I reconstruct this spread of Islam, which included active campaigns to spread Islam among non-Muslims and to get people to relinquish their allegedly un-Islamic ritual objects (or 'fetishes' in the colonial lexicon) and 'traditions' (what some might gloss as African traditional religion). ${ }^{33}$

Although conversion to Islam was the first step some might have taken toward more 'modern' and 'reformist' ideas about Islam, such Islamization in Mali was not an inevitable and unidirectional process of purification as in earlier teleological approaches. Not only was there considerable opposition to Islamization in the region, but 'conversion' was, in some cases, only temporary or led to various - for lack of a better term - 'syncretic' outcomes. In this way, I do not limit my attention to Islam, but I also consider waves of the re-enchantment of non-Islamic 'traditions'. These include those new charismatic non-Muslim religious figures, who called themselves literally 'pagan saints' (Bamana waliju in Bambara), and promised good health, wealth, and success to their followers, clients, and even the postcolonial nation-state. It is in such cases of campaigns to spread Islam and extirpate the un-Islamic along with the appropriation and reworking by non-Muslims of the key Islamic notion of 'saint' in the figure of the 'pagan saint' that one can see the collision and blurring of categories, as well as arenas of debate and contestation.

This particular research is part of a broader shift to take religion seriously as an object of historical study in West Africa but without reifying it or confining one's analysis to Islam or one religious tradition for that matter. Rather than seeing religion as a mere function of political economy, a form of adaptation or resistance, as culture (for example, in quaint and static notions of 'African Islam', or vague and ahistorical formulations such as African traditional religion), or an unfolding teleology of Islamization, reform, and jihad, I am trying to show how one can profitably analyze Islam and other religions within the same analytical frame as a heterogeneous field that entails considerable debate,

32 See also Sean Hanretta's insightful discussion of new religious movements in Africa in S. Hanretta, 'New religious movements', in J. Parker and R. Reid (eds.), The Oxford Handbook of Modern African History (Oxford, 2013), 298-3 I 5 .

33 I have written about some of these processes in B. F. Soares, 'Islam and public piety in Mali', in A. Salvatore and D. E. Eickelman (eds.), Public Islam and the Common Good (Leiden, 2004), 205-26; and in a forthcoming book provisionally entitled, Dogon Muslims and Pagan Saints. 
contestation, and transformation. In this way, I draw on the very rich subfield of the history of Islam in Africa. But I also seek to move beyond some of the existing models and preoccupations with their limitations and try to link up the study of Islam in West Africa with other currents in the historiography and ethnography of Africa and the broader world. 